\title{
EFFECT OF SULPHUR AND ZINC ON CONTENT AND UPTAKE OF NUTRIENTS OF SUMMER GREEN GRAM (VIGNA RADIATA L.WILEZECK) UNDER MEDIUM BLACK CALCAREOUS SOILS
}

\author{
DHARMIK SOLANKI, PAMU SWETHA \& M. S. SOLANKI
}

Department of Agricultural Chemistry and Soil Science, College of Agriculture,

Junagadh Agricultural University, Junagadh, Gujarat, India

\begin{abstract}
A field experiment was conducted during the summer season of 2014, at the Instructional Farm, College of Agriculture, Junagadh Agricultural University, Junagadh to assess the response of summer green gram (Vigna radiata L. Wilezeck) to four levels of sulphur viz., 0, 10, 20 and $30 \mathrm{~kg} \mathrm{~S} \mathrm{ha}{ }^{-1}$, and three levels of Zinc viz., $0,2.5$ and $5.0 \mathrm{~kg} \mathrm{Zn} \mathrm{ha-1.}$

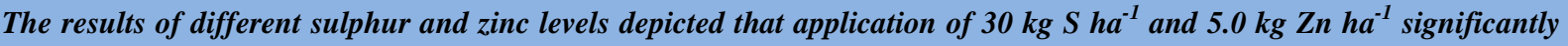
higher in $N, P, K, S$ and Zn content and uptake by seed and straw. Interaction of sulphur and zinc gave significant results.

KEYWORDS: Summer Green Gram, Sulphur Levels, Zinc Levels, Nutrients Content \& Uptake \& Avaialble Nutrients Status
\end{abstract}

Received: Jul 03, 2017; Accepted: Jul 27, 2017; Published: Aug 05, 2017; Paper Id.: IJASRAUG201785

\section{INTRODUCTION}

Mung bean (Vigna radiata L. Wilezeck) has been grown in India, since ancient times. It is also referred to as green gram, golden gram and chop suey bean. Mung bean is grown widely for use as a human food (as dry beans or fresh sprouts), but can be used as a green manure crop and as forage for livestock. The Saurashtra region of Gujarat is being highly influenced by the vagaries of monsoon, which results in low and unstable crop yields. The region faces twin problems of poor fertility and inadequate moisture availability for crop production.

Sulphur, an essential secondary plant nutrient, is required by plant and animals in approximately the same amount as phosphorus. On an average, the amount of sulphur content in the earth crust is ranged about 0.06 to 0.10 per cent. Pulses are particularly responsive to sulphur containing fertilizers, and that elementary sulphur or sulphates increases the percentage of nitrogen as well as yield on such deficient soils.

Micronutrient malnutrition, particularly of $\mathrm{Zn}$, is presently at an alarming proportion in many developing nations (Hortz and Brown, 2004). Spraying micronutrient is beneficial for the growth of green grams and its quality (Khorgami and Farnia, 2006). Zinc deficiency is a major problem, not only because of the direct effect of low $\mathrm{Zn}$ levels, but also because it contributes to susceptibility and progression in other diseases, especially infectious diseases in childhood (Maret and Standstead, 2006). At the same time, the management of sulphur and zinc is must to achieve potential green gram production. 


\section{MATERIAL AND METHODS}

The experiment was conducted during Rabi, season 2013-14 in D-5 plot of Instructional Farm at Krushigadh, College of Agriculture, Junagadh Agricultural University, Junagadh. The experiments were laid out in Factorial Randomized Block Design having 12 treatments with three replications. The experiment consisted of 4 levels of sulphur $(0$, 10,20 and $\left.30 \mathrm{~kg} \mathrm{~S} \mathrm{ha}^{-1}\right)$ and 3 levels of zinc $\left(0,2.5,5 \mathrm{~kg} \mathrm{~S} \mathrm{ha}^{-1}\right)$.

The soil of the experimental field was medium black calcareous soil with $\mathrm{pH} 8.0$ and EC $0.57 \mathrm{dS} \mathrm{m}^{-1}$. The crop was fertilized with sulphur and zinc, as per treatment allotted to each plot in the form of Cosavet fertis, WG (90\%) and $\mathrm{ZnO}$ in basal application. Green gram, GM- 4 variety was used as planting material in this study. The seeds were dibbled at a spacing of $30 \times 10 \mathrm{~cm}$, using a seed rate of $20 \mathrm{~kg} \mathrm{ha}^{-1}$ during the first week of February.

Five plants were selected at random from each plot to record individual plant nutrient content and uptake by some analyses in the leaves, shoot, root and seed. The soil analysis was carried out according to standard methods. The soil used in the experiment was clayey in texture, containing 35.16, 2.97 and 61.87\% sand, silt and clay, respectively. The pH, EC $\left(25^{\circ} \mathrm{C}\right)$ and available $\mathrm{N}, \mathrm{P}, \mathrm{K}, \mathrm{S}$ and $\mathrm{Zn}$ were $8.0,0.57 \mathrm{dS} \mathrm{m}^{-1}$ and $207.30 \mathrm{~kg} \mathrm{ha}^{-1}, 36.80 \mathrm{~kg} \mathrm{ha}^{-1}, 185.70 \mathrm{~kg} \mathrm{ha}^{-1}, 14.38 \mathrm{~kg}$ $\mathrm{ha}^{-1}$ and $0.77 \mathrm{~kg} \mathrm{ha}^{-1}$ respectively. In general, the experimental soil was medium in $\mathrm{N}$ as well as $\mathrm{K}$ and low in $\mathrm{P}$ and $\mathrm{S}$.

\section{RESULTS AND DISCUSSIONS}

\section{Effect of Sulphur}

Application of $30 \mathrm{~kg} \mathrm{~S} \mathrm{ha}^{-1}\left(\mathrm{~S}_{3}\right)$ significantly resulted in higher $\mathrm{N}$ content in seed $(3.73 \%) \&$ straw $(0.85 \%)$, $\mathrm{P}$ content in seed $(0.368 \%)$ \& straw $(0.182 \%), \mathrm{K}$ content in seed $(0.766 \%) \&$ straw $(1.642 \%), \mathrm{S}$ content in seed $(0.168 \%)$ $\&$ straw $(0.107 \%)$ and $\mathrm{Zn}$ content in seed (100.40 ppm) \& straw (15.37 ppm), respectively,

The highest $\mathrm{N}$ uptake by seed $\left(40.56 \mathrm{~kg} \mathrm{ha}^{-1}\right) \&$ straw $\left(16.44 \mathrm{~kg} \mathrm{ha}^{-1}\right), \mathrm{P}$ uptake by seed $\left(4.0 \mathrm{~kg} \mathrm{ha}^{-1}\right) \&$ straw $(3.52$ $\left.\mathrm{kg} \mathrm{ha}^{-1}\right)$, K uptake by seed $\left(8.32 \mathrm{~kg} \mathrm{ha}^{-1}\right) \&$ straw $\left(31.76 \mathrm{~kg} \mathrm{ha}^{-1}\right)$, uptake of S by seed $\left(1.830 \mathrm{~kg} \mathrm{ha}^{-1}\right) \& \mathrm{straw}\left(2.077 \mathrm{~kg} \mathrm{ha}^{-}\right.$ $\left.{ }^{1}\right)$ and $\mathrm{Zn}$ uptake by seed $\left(110.25 \mathrm{~g} \mathrm{ha}^{-1}\right) \&$ straw $\left(29.80 \mathrm{~g} \mathrm{ha}^{-1}\right)$, recoded under $30 \mathrm{~kg} \mathrm{~S}^{-1}$ was significantly superior to the control $\left(\mathrm{S}_{0}\right)$,

It might be due to the fact that sulfur application improves over all nutritional environment of the Rhizosphere, which favors the uptake of nutrients by plant root. Similar results were noticed by Tripathi et al. (1997) for content and uptake of zinc by chickpea, Wasmatkar et al. (2002) for N, P, K and S uptake and Sangale and Sonar (2004) for N and S uptake in soybean and Bansal et al. (1985) for N, P, K and S content in legumes like soybean, green gram, black gram and cowpea with the application of sulphur.

\section{Effect of Zinc}

Different levels of zinc failed to produce significant effect on $\mathrm{N}$ and $\mathrm{K}$ content in green gram seed, it had significantly the highest $\mathrm{N}$ content in straw $(0.81 \%), \mathrm{P}$ content in straw $(0.168 \%), \mathrm{K}$ content in straw $(1.551 \%), \mathrm{S}$ content in seed $(0.143 \%)$ and straw $(0.094 \%)$ and $\mathrm{Zn}$ content in seed $(97.42 \mathrm{ppm})$ and straw (15.84 ppm) was noticed with the application of zinc @ $5.0 \mathrm{~kg} \mathrm{Zn} \mathrm{ha}{ }^{-1}\left(\mathrm{Zn}_{2}\right)$

Increasing levels of zinc produces significant effect. Significantly, the highest N uptake by seed $\left(36.97 \mathrm{~kg} \mathrm{ha}^{-1}\right)$ and straw $\left(15.59 \mathrm{~kg} \mathrm{ha}^{-1}\right), \mathrm{P}$ uptake by seed $\left(3.65 \mathrm{~kg} \mathrm{ha}^{-1}\right)$ and straw $\left(3.23 \mathrm{~kg} \mathrm{ha}^{-1}\right)$, K uptake by seed $\left(6.93 \mathrm{~kg} \mathrm{ha}^{-1}\right)$ and straw $\left(29.72 \mathrm{~kg} \mathrm{ha}^{-1}\right), \mathrm{S}$ uptake by seed $\left(1.483 \mathrm{~kg} \mathrm{ha}^{-1}\right)$ and straw $\left(1.807 \mathrm{~kg} \mathrm{ha}^{-1}\right), \mathrm{Zn}$ uptake by seed $\left(101.13 \mathrm{~g} \mathrm{ha}^{-1}\right)$ and 
straw $\left(30.31 \mathrm{~g} \mathrm{ha}^{-1}\right)$ registered under application of zinc @ $5.0 \mathrm{~kg} \mathrm{ha}^{-1}$.

Zinc is known for utilization of macro-nutrients like $\mathrm{N}$ and $\mathrm{P}$, which might increase the content and uptake of nutrients viz., N, P, K, S and Zn by the crop. Similar results were also noticed by Tayyeba et al. (2013) in green gram, Azad et al. (1993) in lentil and Khorgamy and Farnia (2006) in chickpea.

\section{Interaction Effect}

The S x Zn interaction was found significant effect. Treatment combination of $30 \mathrm{~kg} \mathrm{~S}$ and $5.0 \mathrm{~kg} \mathrm{Zn} \mathrm{ha}{ }^{-1}\left(\mathrm{~S}_{3} \mathrm{Zn}_{2}\right)$ recorded significantly higher $\mathrm{S}$ content in seed $(0.173 \%)$ and straw $(0.120 \%)$ and $\mathrm{Zn}$ content in seed (117.13 ppm) and straw (16.06 ppm), P uptake by straw $\left(3.87 \mathrm{~kg} \mathrm{ha}^{-1}\right), \mathrm{K}$ uptake by straw $\left(34.75 \mathrm{~kg} \mathrm{ha}^{-1}\right), \mathrm{S}$ uptake by seed $\left(2.00 \mathrm{~kg} \mathrm{ha}^{-1}\right)$ and straw $\left(2.48 \mathrm{~kg} \mathrm{ha}^{-1}\right) \& \mathrm{Zn}$ uptake by seed. The increasing levels of both the factors generally recorded higher protein content indicating the synergistic effect of one on another.

\section{CONCLUSIONS}

It might be due to sulphur and zinc that play a vital role in activation of enzymes and in carbohydrate metabolism, which improves the nutrients' uptake. Similar results were noticed by Srivastav et al. (2006), who observed in summer green gram, and Chauhan (2013) and Singh and Singh (1995) in soybean.

\section{REFERENCES}

1. Azad, A. S.; Manchanda, J. S.; Gill, A. S.; Bains, S. S. 1993. Effect of zinc application on grain yield, yield components and nutrient content of lentil. Lens Newsletter 20 (2): 30-33.

2. Bansal 1985. Effect of levels of sulphur on yield and composition of soybean (Glycine max L.), green gram (Vigna radiata L.). Processing of the National Seminar on sulphur in agriculture, pp.177.

3. Chauhan, S. 2013. Effect of Potassium, Sulphur and Zinc On Growth, Yield and Oil content in Soybean in vertisol of central india. Indian Journal of Applied Research. 3: 489 - 491.

4. Hortz, C. and Brown, K. H. 2004. Assessment of the risk of Zinc deficiency in populations and options for its control. Food Nutrition Bulletin, 25: 94-103.

5. Khorgami, A. and Farnia, A. 2006. Effect of phosphorus and zinc fertilization on yield and yield components of chick pea cultivars. African Crop Science Conference Proceedings, 9: 205-208.

6. Maret, W. and Standstead, H. 2006. Zinc requirement and rises and benefit of Zinc supplementation. Journals of Trace Elements Medical Biology, 20: 3-18.

7. Sangale, R. V. and Sonar, K. R. 2004. Yield and quality of soybean as influenced by sulphur application. Journal of Maharashtra Agricultural University, 29(1):117-118.

8. Singh, S. K. and Singh, G. C. 2013. Effect of phosphorus, sulphur and zinc on nutrient composition in black gram. The Journal of Rural and Agricultural Research, 13(2):63-64.

9. Srivastava, A. K.; Tripathi, P. N.; Singh, A. K. and Singh, R. 2006. Effect of rhizobium, sulphur and zinc levels on growth, yield, nutrient uptake and quality of summer green gram (Phaseolus radiatus L.). International Journal of Agriculture Science, $2(1): 190-192$.

10. Tayyeba. S.; Humaira, Hamid. U. S.; Saleem. U. and Muhammad. J. 2013. Zinc effect on growth rate, chlorophyll, protein and mineral contents on hydroponically grown mungbeans plant (Vigna radiata). Arabian Journal oh Chemistry, 27(3): 120-122. 
11. Tripathi, H. C.; Singh, R. S. and Mishra, V. K. 1997. Effect of S and Zn nutrition on yield and quality of chickpea. (Cicer arietinum L.). Journal of the Indian Society of Soil Science, 45(1): 123-126.

12. Wasmatkar, R. P.; Ingole, G. L., and Raut, P. D. 2002. Effect of different levels of sulphur and zinc on quality and uptake of nutrient of soybean. Journal of Maharashtra Agricultural University, 27(3):244-246.

\section{APPENDICES}

Table 1: Effect of Sulphur and Zinc on Content of N, P, K, S and Zn by Seed and Straw

\begin{tabular}{|c|c|c|c|c|c|c|c|c|c|c|}
\hline \multirow[t]{2}{*}{ Treatments } & \multicolumn{2}{|c|}{$\begin{array}{c}\text { N Content } \\
(\%)\end{array}$} & \multicolumn{2}{|c|}{$\begin{array}{c}\text { P Content } \\
(\%)\end{array}$} & \multicolumn{2}{|c|}{$\begin{array}{c}\text { K Content } \\
(\%)\end{array}$} & \multicolumn{2}{|c|}{$\begin{array}{c}\text { S Content } \\
(\%)\end{array}$} & \multicolumn{2}{|c|}{$\begin{array}{c}\text { Zn Content } \\
(\%)\end{array}$} \\
\hline & Seed & Straw & Seed & Straw & Seed & Straw & Seed & Straw & Seed & Straw \\
\hline \multicolumn{11}{|c|}{ Levels of Sulphur $\left(\mathrm{Kg} \mathrm{Ha}^{-1}\right)$} \\
\hline $\mathrm{S}_{0}: 00$ & 3.45 & 0.74 & 0.328 & 0.153 & 0.589 & 1.382 & 0.119 & 0.076 & 79.20 & 14.71 \\
\hline $\mathrm{S}_{1}: 10$ & 3.48 & 0.76 & 0.362 & 0.156 & 0.614 & 1.509 & 0.125 & 0.080 & 82.25 & 15.02 \\
\hline $\mathrm{S}_{2}: 20$ & 3.63 & 0.81 & 0.366 & 0.165 & 0.681 & 1.548 & 0.153 & 0.090 & 85.89 & 15.07 \\
\hline $\mathrm{S}_{3}: 30$ & 3.73 & 0.85 & 0.368 & 0.182 & 0.766 & 1.642 & 0.168 & 0.107 & 100.40 & 15.37 \\
\hline S. Em. \pm & 0.05 & 0.01 & 0.009 & 0.001 & 0.009 & 0.016 & 0.001 & 0.001 & 2.45 & 0.11 \\
\hline $\mathrm{CD}(\mathrm{P}=0.05)$ & 0.15 & 0.04 & 0.025 & 0.003 & 0.026 & 0.048 & 0.003 & 0.004 & 7.17 & 0.32 \\
\hline \multicolumn{11}{|c|}{ Levels of Zinc $\left(\mathrm{kg} \mathrm{ha}^{-1}\right)$} \\
\hline $\mathrm{Zn}_{0}: 0$ & 3.54 & 0.79 & 0.348 & 0.161 & 0.653 & 1.488 & 0.139 & 0.083 & 75.97 & 14.17 \\
\hline $\mathrm{Zn}_{1}: 2.5$ & 3.58 & 0.77 & 0.365 & 0.163 & 0.664 & 1.521 & 0.141 & 0.088 & 87.40 & 15.12 \\
\hline $\mathrm{Zn}_{2:} 5.0$ & 3.60 & 0.81 & 0.355 & 0.168 & 0.671 & 1.551 & 0.143 & 0.094 & 97.42 & 15.84 \\
\hline S. Em. \pm & 0.04 & 0.01 & 0.007 & 0.001 & 0.008 & 0.014 & 0.001 & 0.001 & 2.12 & 0.10 \\
\hline $\mathrm{CD}(\mathrm{P}=0.05)$ & $\mathrm{NS}$ & 0.03 & NS & 0.003 & NS & 0.041 & 0.003 & 0.004 & 6.21 & 0.28 \\
\hline $\mathbf{S} \times \mathbf{Z n}$ Interaction & $\mathrm{NS}$ & $\mathrm{NS}$ & NS & NS & NS & NS & Sig. & Sig. & Sig. & Sig. \\
\hline $\mathrm{CV} \%$ & 4.25 & 4.84 & 7.28 & 2.14 & 4.00 & 3.21 & 2.18 & 4.98 & 8.44 & 2.19 \\
\hline
\end{tabular}

Table 2: Effect of Sulphur and Zinc on Uptake of N, P, K, S and Zn by Seed and Straw

\begin{tabular}{|c|c|c|c|c|c|c|c|c|c|c|}
\hline \multirow[t]{2}{*}{ Treatments } & \multicolumn{2}{|c|}{$\begin{array}{c}\text { N Uptake (Kg } \\
\left.\mathrm{Ha}^{-1}\right)\end{array}$} & \multicolumn{2}{|c|}{$\begin{array}{c}\text { P Uptake (Kg } \\
\left.\mathrm{Ha}^{-1}\right)\end{array}$} & \multicolumn{2}{|c|}{$\begin{array}{c}\text { K Uptake (Kg } \\
\left.\text { Ha }^{-1}\right)\end{array}$} & \multicolumn{2}{|c|}{$\begin{array}{c}\text { S Uptake (Kg } \\
\left.\mathrm{Ha}^{-1}\right)\end{array}$} & \multicolumn{2}{|c|}{$\begin{array}{c}\text { Zn Uptake } \\
\left(\mathrm{Kg} \mathrm{Ha}^{-1}\right)\end{array}$} \\
\hline & Seed & Straw & Seed & Straw & Seed & Straw & Seed & Straw & Seed & Straw \\
\hline \multicolumn{11}{|c|}{ Levels of Sulphur $\left(\mathrm{Kg} \mathrm{Ha}^{-1}\right)$} \\
\hline $\mathrm{S}_{0}: 00$ & 30.88 & 12.36 & 2.93 & 2.55 & 5.28 & 23.15 & 1.063 & 1.272 & 71.39 & 24.74 \\
\hline $\mathrm{S}_{1}: 10$ & 32.44 & 13.40 & 3.37 & 2.76 & 5.74 & 26.69 & 1.165 & 1.425 & 78.43 & 26.62 \\
\hline$S_{2}: 20$ & 35.02 & 15.41 & 3.53 & 3.13 & 6.57 & 29.28 & 1.471 & 1.703 & 82.97 & 28.55 \\
\hline $\mathrm{S}_{3}: 30$ & 40.56 & 16.44 & 4.00 & 3.52 & 8.32 & 31.76 & 1.830 & 2.077 & 110.25 & 29.80 \\
\hline S. Em. \pm & 0.94 & 0.31 & 0.13 & 0.05 & 0.19 & 0.36 & 0.032 & 0.044 & 4.33 & 0.55 \\
\hline $\mathrm{CD}(\mathrm{P}=0.05)$ & 2.76 & 0.91 & 0.38 & 0.14 & 0.56 & 1.07 & 0.093 & 0.128 & 12.71 & 1.61 \\
\hline \multicolumn{11}{|c|}{ Levels of Zinc $\left(\mathrm{kg} \mathrm{ha}^{-1}\right)$} \\
\hline $\mathrm{Zn}_{0}: 0$ & 32.25 & 13.50 & 3.17 & 2.76 & 5.98 & 25.57 & 1.276 & 1.437 & 69.92 & 24.30 \\
\hline $\mathrm{Zn}_{1}: 2.5$ & 34.94 & 14.12 & 3.56 & 2.98 & 6.52 & 27.87 & 1.389 & 1.613 & 86.23 & 27.68 \\
\hline $\mathrm{Zn}_{2:} 5.0$ & 36.97 & 15.59 & 3.65 & 3.23 & 6.93 & 29.72 & 1.483 & 1.807 & 101.13 & 30.31 \\
\hline S. Em. \pm & 0.81 & 0.27 & 0.11 & 0.04 & 0.16 & 0.31 & 0.027 & 0.038 & 3.75 & 0.47 \\
\hline $\mathrm{CD}(\mathrm{P}=0.05)$ & 2.39 & 0.79 & 0.33 & 0.12 & 0.48 & 0.92 & 0.081 & 0.111 & 11.01 & 1.39 \\
\hline $\mathbf{S} \times \mathbf{Z n}$ Interaction & NS & NS & NS & Sig & NS & Sig. & Sig. & Sig. & Sig. & NS \\
\hline $\mathrm{CV} \%$ & 8.12 & 6.50 & 11.37 & 4.85 & 8.81 & 3.93 & 6.87 & 8.09 & 15.16 & 5.99 \\
\hline
\end{tabular}


Table 3: Interaction Effect of S and Zn on S \& Zn Content in Seed and Straw

\begin{tabular}{|c|c|c|c|c|c|c|c|c|c|c|c|c|c|c|c|c|}
\hline \multirow{4}{*}{ Level of Zinc } & \multicolumn{16}{|c|}{ Level Of Sulphur } \\
\hline & \multicolumn{8}{|c|}{ Seed } & \multicolumn{8}{|c|}{ Straw } \\
\hline & \multicolumn{4}{|c|}{ SContent (\%) } & \multicolumn{4}{|c|}{ Zn Content (Ppm) } & \multicolumn{4}{|c|}{ SContent (\%) } & \multicolumn{4}{|c|}{ Zn Content (Ppm) } \\
\hline & $\mathrm{S}_{0}$ & $\mathrm{~S}_{1}$ & $\mathrm{~S}_{2}$ & $\mathrm{~S}_{3}$ & $\mathrm{~S}_{0}$ & $\mathrm{~S}_{1}$ & $\mathrm{~S}_{2}$ & $\mathrm{~S}_{3}$ & $\mathrm{~S}_{0}$ & $S_{1}$ & $\mathrm{~S}_{2}$ & $\mathrm{~S}_{3}$ & $\mathrm{~S}_{0}$ & $\mathrm{~S}_{1}$ & $\mathrm{~S}$ & $\mathrm{~S}_{3}$ \\
\hline $\mathrm{Zn}_{0}$ & 0.116 & 0.126 & 0.151 & 0.164 & 74.50 & 66.14 & 81.22 & 82.01 & 0.074 & 0.078 & 0.087 & 0.096 & 13.72 & 14.10 & 14.42 & 14.43 \\
\hline $\mathrm{Zn}_{1}$ & 0.120 & 0.127 & 0.149 & 0.169 & 80.01 & 82.90 & 84.67 & 102.03 & 0.076 & 0.081 & 0.090 & 0.104 & 14.50 & 15.40 & 14.97 & 15.62 \\
\hline $\mathrm{Zn}$ & 0.122 & 0.124 & 0.158 & 0.173 & 83.08 & 97.69 & 91.78 & 117.13 & 0.079 & 0.084 & 0.094 & 0.120 & 15.92 & 15.55 & 15.83 & 16.06 \\
\hline S.Em. \pm & \multicolumn{4}{|c|}{0.001} & \multicolumn{4}{|c|}{4.23} & \multicolumn{4}{|c|}{0.001} & \multicolumn{4}{|c|}{0.19} \\
\hline $\mathrm{CD}(\mathrm{P}=0.05)$ & \multicolumn{4}{|c|}{0.003} & \multicolumn{4}{|c|}{12.48} & \multicolumn{4}{|c|}{0.003} & \multicolumn{4}{|c|}{0.56} \\
\hline C.V.\% & \multicolumn{4}{|c|}{2.48} & \multicolumn{4}{|c|}{8.44} & \multicolumn{4}{|c|}{4.98} & \multicolumn{4}{|c|}{2.19} \\
\hline
\end{tabular}

Table 4: Interaction Effect of $S$ and Zn on S \& Zn Uptake by Seed and P, K \& S Uptake by Straw

\begin{tabular}{|c|c|c|c|c|c|c|c|c|c|c|c|c|c|c|c|c|c|c|c|c|}
\hline \multirow{4}{*}{ Level of Zinc } & \multicolumn{20}{|c|}{ Level of Sulphur } \\
\hline & \multicolumn{8}{|c|}{ Seed } & \multicolumn{12}{|c|}{ Straw } \\
\hline & \multicolumn{4}{|c|}{ S Uptake $\left(\mathrm{kg} \mathrm{ha}^{-1}\right)$} & \multicolumn{4}{|c|}{ Zn Uptake (kg ha $\left.{ }^{-1}\right)$} & \multicolumn{4}{|c|}{ P Uptake (kg ha-1) } & \multicolumn{4}{|c|}{ KUptake (kg ha $\left.{ }^{-1}\right)$} & \multicolumn{4}{|c|}{ SUptake $\left(\mathrm{kg} \mathrm{ha}^{-\mathrm{l}}\right)$} \\
\hline & $\mathrm{S}_{0}$ & $\mathrm{~S}_{\mathrm{l}}$ & $S_{1}$ & $S_{3}$ & $\mathrm{~S}_{0}$ & $\mathrm{~S}_{\mathrm{l}}$ & $S_{1}$ & $S_{3}$ & $\mathrm{~S}_{0}$ & $\mathrm{~S}_{1}$ & $S_{1}$ & $S_{3}$ & $\mathrm{~S}_{0}$ & $S_{1}$ & $S_{l}$ & $S_{3}$ & $S_{0}$ & $\mathrm{~S}_{\mathrm{l}}$ & $S_{1}$ & $S_{3}$ \\
\hline $2 n_{0}$ & 1.06 & 1.00 & 1.41 & 1.63 & 68.91 & 53.03 & 75.89 & 81.85 & 2.26 & 2.67 & 2.95 & 3.16 & 19.91 & 25.73 & 27.88 & 28.78 & 1.10 & 1.35 & 1.58 & 1.71 \\
\hline $\mathrm{Zn}_{\mathrm{l}}$ & 1.08 & 1.21 & 1.42 & 1.85 & 72.92 & 78.59 & 80.85 & 112.59 & 2.65 & 2.77 & 2.99 & 3.52 & 24.21 & 26.86 & 28.64 & 31.76 & 1.32 & 1.44 & 1.66 & 2.04 \\
\hline $\mathrm{Zn}$ & 1.05 & 1.29 & 1.58 & 2.00 & 72.35 & 103.69 & 92.18 & 136.32 & 2.75 & 2.85 & 3.44 & 3.87 & 25.33 & 27.50 & 31.32 & 34.75 & 1.39 & 1.49 & 1.87 & 2.48 \\
\hline S.Em. \pm & \multicolumn{4}{|c|}{0.05} & \multicolumn{4}{|c|}{7.75} & \multicolumn{4}{|c|}{0.08} & \multicolumn{4}{|c|}{0.63} & \multicolumn{4}{|c|}{$\begin{array}{l}0.08 \\
\end{array}$} \\
\hline $\begin{array}{l}\mathrm{CD} \quad(\mathrm{P}= \\
0.05)\end{array}$ & \multicolumn{4}{|c|}{0.16} & \multicolumn{4}{|c|}{22.01} & \multicolumn{4}{|c|}{0.25} & \multicolumn{4}{|c|}{1.85} & \multicolumn{4}{|c|}{0.22} \\
\hline C.V.\% & \multicolumn{4}{|c|}{6.88} & \multicolumn{4}{|c|}{15.16} & \multicolumn{4}{|c|}{4.85} & \multicolumn{4}{|c|}{3.93} & \multicolumn{4}{|c|}{8.10} \\
\hline
\end{tabular}

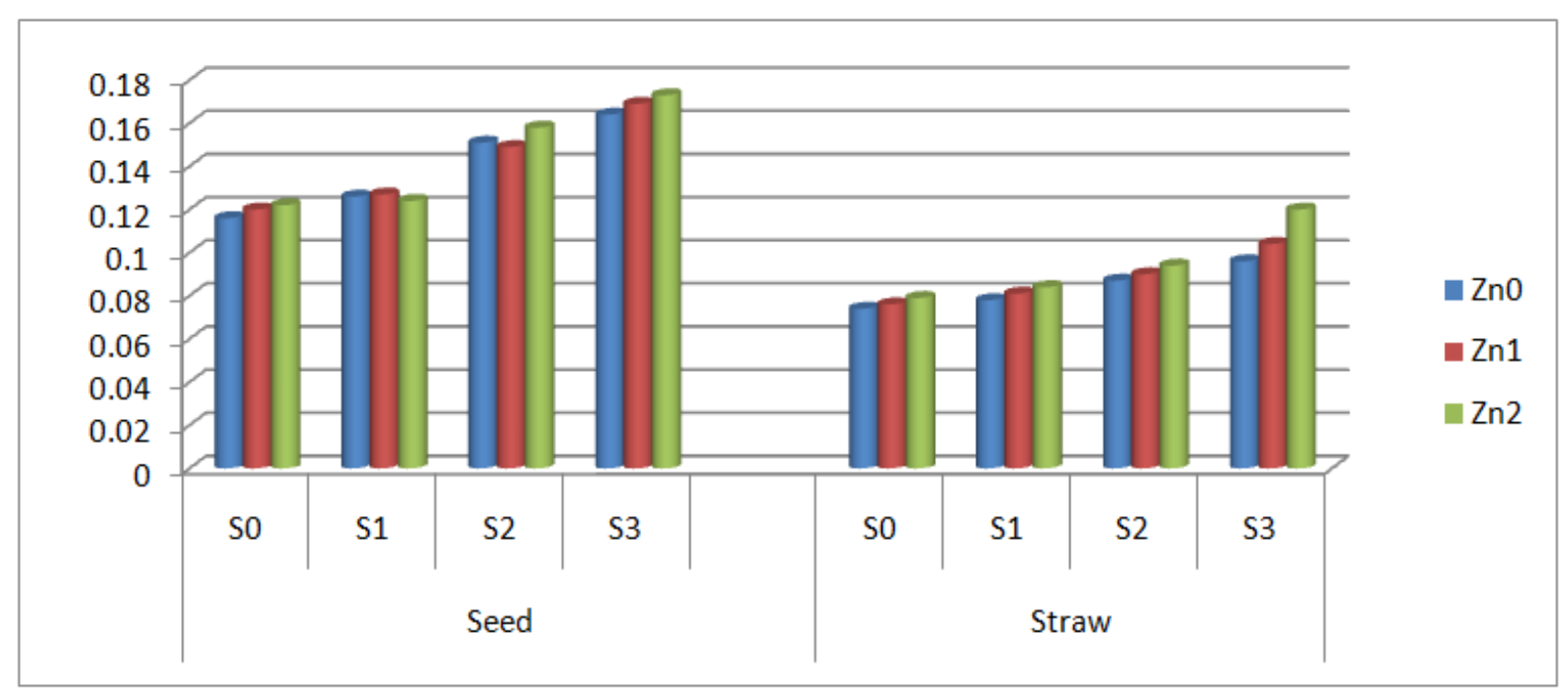

Figure 1: Interaction Effect of S and Zn on S Content in Seed and Straw 


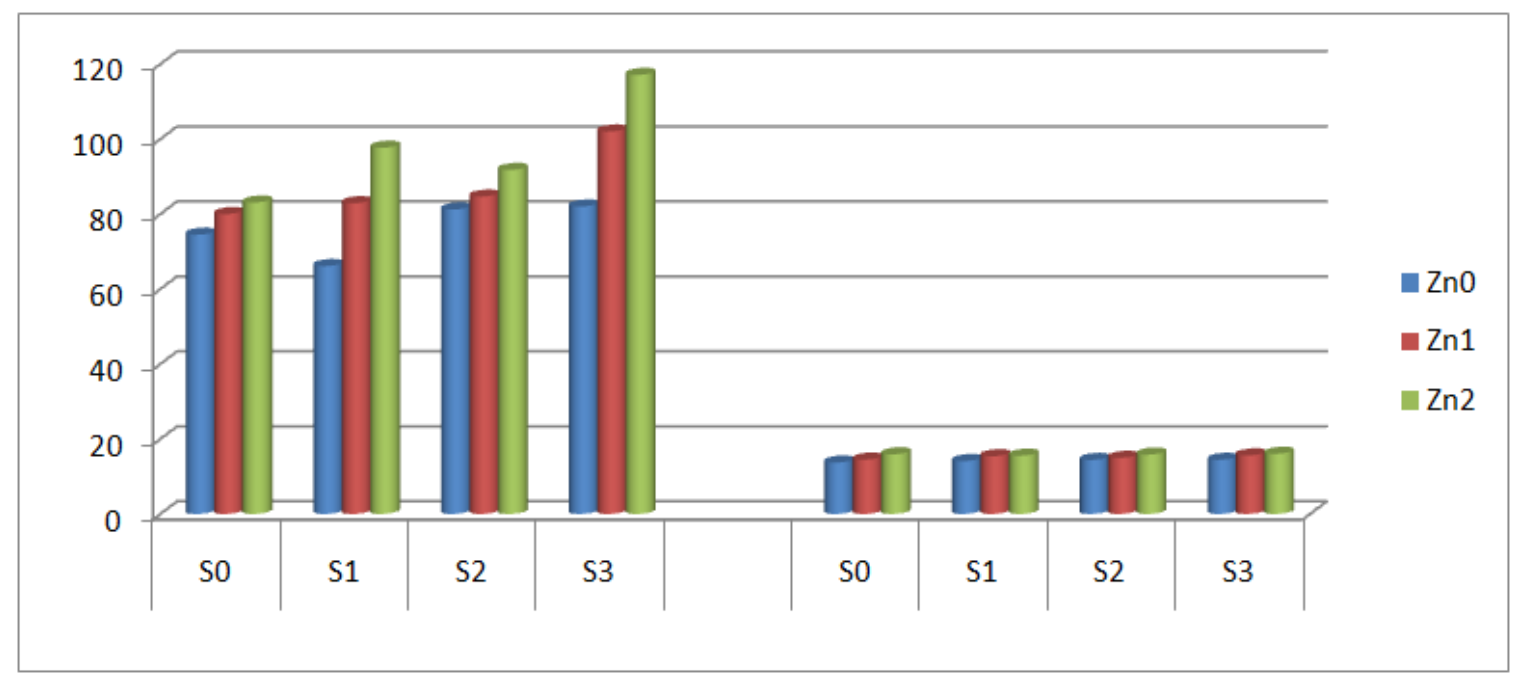

Figure 2: Interaction Effect of $S$ and $\mathrm{Zn}$ on $\mathrm{Zn}$ Content in Seed and Straw 